\title{
Comments on distribution and taphonomy of Devonian placoderms in the Holy Cross Mountains, Poland
}

\author{
PIOTR SZREK
}

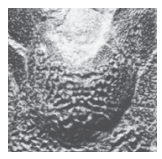

\begin{abstract}
Taphonomy, stratigraphical occurrences and geographical distribution of Devonian placoderms in the Holy Cross Mountains described by former researchers is revised. Four main types of preservation states occur in the placoderm fossils of that region. Fossil preservation depends on geodynamic processes. Mechanical damage appears to be the main factor explaining the final state of preservation. For most of the previously described as well as the new specimens, the occurrences were dated biostratigraphically by palynomorphs and conodonts. The taxonomic distribution of placoderms in space and time within the Devonian strata in the Holy Cross Mountains correlates well with the Devonian nekton revolution, but it is also controlled by the regional palaeoecology and local synsedimentary tectonics of the carbonate platform. - Key words: Placodermi, Devonian, distribution, taphonomy, Holy Cross Mountains, Poland.
\end{abstract}

SzreK, P. 2020. Comments on distribution and taphonomy of Devonian placoderms in the Holy Cross Mountains, Poland. Bulletin of Geosciences 95(1), 23-39 (7 figures, 2 tables). Czech Geological Survey, Prague. ISSN 1214-1119. Manuscript received June 4, 2019; accepted in revised form December 16, 2019; published online January 21, 2020; issued March 31, 2020.

Piotr Szrek, Polish Geological Institute-National Research Institute, 4 Rakowiecka Street, 00-975 Warsaw, Poland; piotr. szrek@pgi.gov.pl \& University of Warsaw, Faculty of Geology, Żwirki i Wigury Street 93, 02-089 Warsaw, Poland

Placodermi McCoy, 1848 (armoured fishes) are a group of early jawed vertebrates that appeared in the Silurian period and reached maximum diversification during the Devonian. Placoderms became extinct at the end of the Devonian. Placoderms played an important role in the history of geological studies in the Holy Cross Mountains. Initially, the placoderms were used as stratigraphic tools to distinguish between the Cambrian and Devonian sandstones in the Holy Cross Mountain region (Czarnocki 1919, 1936). Placoderms were used as a biostratigraphic marker for correlation for the first time by Kontkiewicz (1882) and this was applied to the mining activity that occurred between 1893 and 1895 (Kosmowska-Ceranowicz 1973). Gürich (1896), Czarnocki (1919, 1936) and other authors followed Kontkiewicz's concept of employing placoderms as index fossils to recognize Early Devonian. By contrast, placoderms served rather limited biostratigraphic value for younger Devonian strata. However they were useful in determining crucial details of the palaeo-environment, especially the sediments deposited under marine conditions (Kulczycka 1933; GorizdroKulczycka 1934, 1949, 1950; Samsonowicz 1934). One could say that the modern study of placoderms from Poland commences with Kulczycki's investigations in 1956 and 1957, where he provided comprehensive data of the stratigraphical and geographical distribution of placoderms and correlated these occurrences with other areas. However, Kulczycki worked prior to the publication of Wegener's theory of continental drift, resulting in some erroneous palaeogeographic conclusions, but his correlations of the Late Devonian American, West-European and Polish assemblages are still quite important (Kulczycki 1957). So far, other vertebrate remains in the studied horizons reveal little information. Surprisingly, not much has been published on placoderm taxonomy and their spatial and stratigraphic distribution in the Holy Cross Mountains. Thus, the main goal of this article is to summarize and discuss the placoderm record, their preservation and taphonomy in the Holy Cross Mountains using published data (Kontkiewicz 1882; Gürich 1896; Siemiradzki 1903; Czarnocki 1919, 1936; Kulczycka 1933; Samsonowicz 1934; Gorizdro-Kulczycka 1934, 1949, 1950; Kulczycki 1956, 1957; Liszkowski \& Racki 1993; Ivanov \& Ginter 1997; Szrek 2000, 2003, 2004, 2006a, b, 2007a, b, c, 2008; Szrek \& Ginter 2007; Gorzelak et al. 2010; Szrek et al. 2014, 2015; Dworczak \& Szrek 2016; Szrek \& Dupret 2017; Szrek \& Wilk 2018). This study also includes recent, unpublished discoveries including new material.

\section{Geologic and stratigraphic framework}

The Holy Cross Mountains is a geological region of Central Poland divided into two units, namely Łysogóry 
A
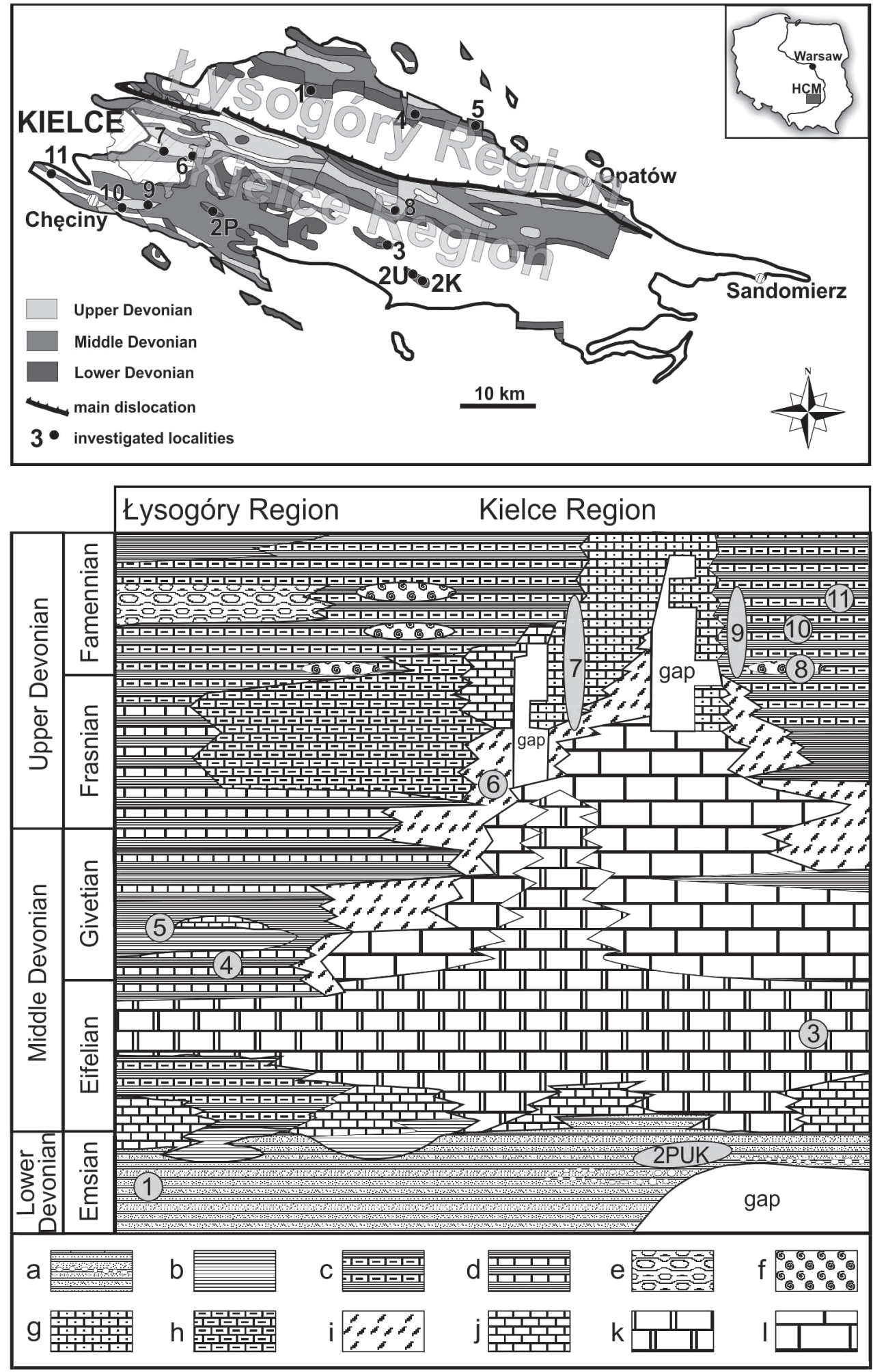

Figure 1. A - locality map of the Holy Cross Mountains (HCM), Central Poland (modified from Kowalczewski 1971). • B - diagrammatic cross section through the Holy Cross Mountains from the Givetian to the top of the Upper Devonian (after Szulczewski 1995, modified) with the probable position of the investigated localities ( $\mathrm{a}$ - silty shales, sandstones, conglomerates; $\mathrm{b}$ - clayey and marly shales; $\mathrm{c}$ - marly limestones and shales; $\mathrm{d}$ - marly limestones; e - nodular limestones; f - cephalopod limestones; g - condensed cephalopod and crinoidal limestonesl; $\mathrm{h}$ - micrites, calcarenites, calcirutides; $\mathrm{i}$ - calcirudites; $\mathrm{j}$ - bedded limestones; $\mathrm{k}$ - dolomites; 1 - massive and bedded limestone). Abbreviations: 1 - Bukowa Mountain; 2 - Podłazie (P); Ujazd (U); Kopiec (K); 3 - Bardo Górne; 4 - Tarczek; 5 - Skały; 6 - Wietrznia; 7 - Kadzielnia; 8 - Płucki; 9 - Kowala; 10 - Jaźwica; 11 - Gałęzice/Ostrówka. 
in the north and Kielce in the south (Fig. 1A, B). Each region has its own geological history and different palaeogeographical position from the Cambrian to the Devonian (Domeier \& Torsvik 2014, Nawrocki et al. in press). Differences in facies development during the Devonian include predominantly marine conditions in the Łysogóry region and more continental tectonic conditions in the Kielce region (Szulczewski 1995). Moreover, the Devonian profile in the Łysogóry region is almost complete while in the Kielce region, it is characterised by several unconformities and gaps (see Szulczewski 1995, Fig. 1). The differences in the palaeontological record in the Early Devonian deposits are also significant. The Łysogóry region yielded a rich assemblage of invertebrate fossils and ichnofossils (Szulczewski 1995, Szulczewski \& Porębski 2008) as well as vertebrate remains (Szrek et al. 2015). In the Kielce region, there are no invertebrate fossils (Szrek et al. 2014, 2016) while the vertebrate remains are numerous and diversified (Tarlo 1957, 1961a, b, 1962, 1964, 1965; Kulczycki 1960; Blieck 1980; Szrek et al. 2014, 2015; Szrek \& Dupret 2017). Close to the Lower-Middle Devonian boundary, siliciclastic deposition ended and a carbonate platform developed. This reflects multiple transgressive-regressive pulses and a three-phase evolution of the carbonate platform, including peritidal to bank-sedimentation and reef growth followed by a post-reef phase of disintegration and drowning (Szulczewski 1971, 1995; Racki 1993; Racki et al 2002). The Late Devonian carbonate platform facies of the studied area is established on the wide platform, which was divided into blocks during the Frasnian and submerged in several steps (Szulczewski 1989, 1995). The submersion of the carbonate platform was possibly caused by synsedimentary block tectonics (Szulczewski 1989, 1995, 2006; Racki 1993) during a period of intense tectonic activity (McGhee 2013). The tectonic activity resulted in the collision of the major continental crustal blocks, such as Laurussia, Gondwana, Kazakhstan and Siberia during the so-called Acadian-Variscan Mountain building event over the course of about 50 million years (Averbuch et al. 2005). In the Holy Cross Mountains, this tectonic activity is mostly manifested by the carbonate platform fragmentation into blocks, which is reflected in neptunian dykes with hydrothermal mineralization (Szulczewski 1973, Szulczewski et al. 1996) and distinct facies differentiation (e.g. Sobolev 1912; Szulczewski 1971, 1989). This tectonic activity is also linked to several intraformational erosional pulses documented by coarse breccias, conglomerates and underwater slumps (Radwański \& Roniewicz 1962; Szulczewski 1968, 1971; Kaźmierczak \& Goldring 1978; Racki 1993). Sinking of the Devonian carbonate platform ended during the Viséan and contributed to the development of a deep-sea pelagic platform (Szulczewski 1989, 1995; Racki 1993; Szulczewski et al. 1996).
An important supplement to the discussion of the differences between the Łysogóry and Kielce regions, especially during the Early Devonian, is the recent finding that the vertebrate faunas in both regions contain the same components including (except the placoderms) agnathans, acanthodians and sarcopterygians. The only difference can be explained by the more terrestrial conditions in the Kielce region in contrast to more marine conditions in Łysogóry. Based on the vertebrate fauna, Czarnocki $(1919,1936)$ reported the same species for both Łysogóry and Kielce, notably Machaeracanthus polonicus. Later, Pawłowska $(1954,1961)$ discussed the stratigraphic sequences in both regions, and accepted Czarnocki's assessment of the different origins for the northern and southern facies in the Devonian period of the Holy Cross Mountains. Tarlo (1957) stated that Czarnocki (1936) disregarded vertebrates as potentially useful age indicators. However, despite acknowledging that he had collected the same fauna in the northern and southern regions, Tarlo still considered that the correlation between the two regions is debatable.

\section{Material}

Although the majority of the accessible material was collected during the last 25 years, most of the formally described specimens were collected during field work campaigns in the first half of the $20^{\text {th }}$ century. The material was collected in four main stages:

1) In the $19^{\text {th }}$ century, Stanisław Kontkiewicz collected a large amount of Early Devonian fossils, which were described by Gürich (1896) and Czarnocki (1919, 1936). Unfortunately, the repository of Kontkiewicz's collection is unknown (Kosmowska-Ceranowicz 1973).

2) Between 1910 and 1945, Jan Czarnocki collected most of the Late Devonian specimens described by Zinaida Gorizdro-Kulczycka and partially by Julian Kulczycki (Woroncowa-Marcinowska \& Szrek 2004).

3) Between 1946 and 1956, Gorizdro-Kulczycka and Kulczycki provided excavations in the Kadzielnia, Wietrzna and Podłazie quarries and collected Early and Late Devonian materials.

4) Since 1995 to present, the author of this publication continues the search for fish fossils in the entire Devonian of the Holy Cross Mountains (e.g. Szrek 2004, 2008; Szrek et al. 2015; Dworczak \& Szrek 2016; Szrek \& Dupret 2017; Szrek \& Wilk 2018). Single finds of placoderms are described occasionally by geologists who work in associated fields in the same region (with special reference to scientists from the Department of Earth Sciences of the University of Silesia in Sosnowiec - see Szrek 2004, Dworczak \& Szrek 2016) and also by amateur collectors. 
Currently, the majority of the placoderm fossils (and Devonian vertebrates in general) are stored in Warsaw in three collections: in the Museum of the Earth of the Polish Academy of Sciences (coll. MZ VIII Vp), at the Faculty of Geology of the University of Warsaw (coll. MWG UW ZI/43) and in the Polish Geological InstituteNational Research Institute (coll. Muz. PGI-NRI 5.II, Muz. PGI-NRI 1733.II and Muz. PGI-NRI 1809.II). Single specimens are also owned by the Institute of Paleobiology, the Polish Academy of Sciences, Warsaw (ZPAL P.VI) and by the Faculty of Earth Sciences of the University of Silesia, Sosnowiec (WNaZ/S/4). Some additional specimens are in the private collections of amateur researchers.

\section{Distribution}

Ivanov \& Ginter (1997) mentioned six localities where placoderms (Late Devonian in age) and other vertebrates have been found in the Holy Cross Mountains. They listed placoderms from four localities exposing the Early Devonian, three localities exposing the Middle Devonian and nine localities exposing Late Devonian (16 sites totally). These sections are discussed and briefly described below.

\section{Early Devonian (Emsian)}

The Early Devonian placoderms of the Holy Cross Mountains have been studied for a long time. The first reports of their occurrence in the Lower Devonian of the Holy Cross Mountains were those of Kontkiewicz (1882) and Michalski (1884). However, both authors never provided detailed fossil descriptions. Theirs and Gürich's (1896) identifications have become a source of inspiration for successive authors (Tab. 1). It is remarkable that so many occurrences of Coccosteus and Pterichthys have been reported from Early Devonian strata of the Holy Cross Mountains (Tab. 1). The lack of illustrations and original specimens renders it impossible to determine whether those authors really saw true Coccosteus and Pterichthys or just similar remains. Fossils of Coccosteus are generally of Middle Devonian age (Eifelian) and it is highly likely that most of these authors repeated the incorrect identifications of Gürich (1896). At the end of the $19^{\text {th }}$ century, Coccosteus and Pterichthys were well known from the British Old Red-Sandstone and were very often illustrated (e.g. Lyell 1885, fig. 500; Woodward 1885, figs 26, 28; 1891, fig. 44, pls 5-8; Neumayr 1895, fig. 36). I assume that these authors were misled by the tubercles covering dermal bones of Coccosteus (e.g. Woodward 1885, fig. 28; 1891, pls 7, 8), which re- semble the ornamentation on moulds of sarcopterygians and actinolepid placoderms in the placoderm sandstone. The same holds true for the supposed occurrences of "Bothriolepis" and "Asterolepis", which could not be verified in the latest studies (Szrek \& Dupret 2017). The last problematic genus Heterostius presents a different case. It is quite probable that this identification is correct, because of the recent description of Heterostius (Szrek et al. 2015) from the contemporary deposits of the Lysogóry region. Recently, a fragment of the skull-roof of the homosteid arthrodire has been reported from the Podłazie locality (Kielce region) and it probably represents the same taxon as was described from the Emsian stage of the Bukowa Góra quarry (Łysogóry region; Szrek et al. 2015) and demonstrates its wider distribution in space and time; the Podłazie section is older or at least of the same age as the Bukowa Góra section - see discussion in Szrek et al. (2015) and Szrek \& Dupret (2017).

Czarnocki $(1919,1936)$ and Filonowicz (1968) mentioned the occurrence of a two-metre thick bone-bearing breccia in the Dębska Wola region. Those authors reported that in this breccia, a very rich and well-preserved vertebrate fossil assemblage occurs. Unfortunately, these authors did not provide details apart from the general information about the locality. Despite numerous attempts to find the site mentioned by Czarnocki $(1919,1936)$ and Filonowicz (1968), I could not trace the exact location.

Paradoxically, no actual placoderm from the "placoderm sandstone" had been illustrated until the study of Szrek \& Dupret (2017). We described and illustrated an assemblage of placoderms exactly 111 years after the name "placoderm sandstone" was introduced. The "placoderm sandstone" now comprises the youngest representatives of the Kujdanowiaspis fauna assemblage as well as unidentified actinolepids and brachythoracid arthrodires. Szrek \& Dupret (2017) supplemented and corrected Szrek's (2003) data published earlier, in which the author of this publication identified questionable antiarch and arthrodire remains. Three specimens illustrated in that paper (Szrek 2003, figs 2b, c, 3b) were misinterpreted and should better be referred to as indeterminable vertebrates (probably placoderm or sarcopterygian remains).

\section{Middle Devonian (Eifelian)}

The Middle Devonian placoderms are known only from three localities and comprise very few specimens. The Tarczek locality in the Świętomarz-Śniadka section revealed an indeterminable fragment of a dermal plate, probably belonging to a brachythoracid arthrodire. The Bardo Górne locality revealed very few fragments including the median dorsal plate of an acanthothoracid placoderm, the first member of this order from Poland. In 
Table 1. Occurrence and history of findings of Early Devonian placoderms in the Holy Cross Mountains. Abbreviations: (-) - historical sites not exist anymore and/or negatively verified for placoderms occurrence; $(+)$ - sites with placoderms remains placed on the map (Fig. 1A) and cross-section (Fig. 1B).

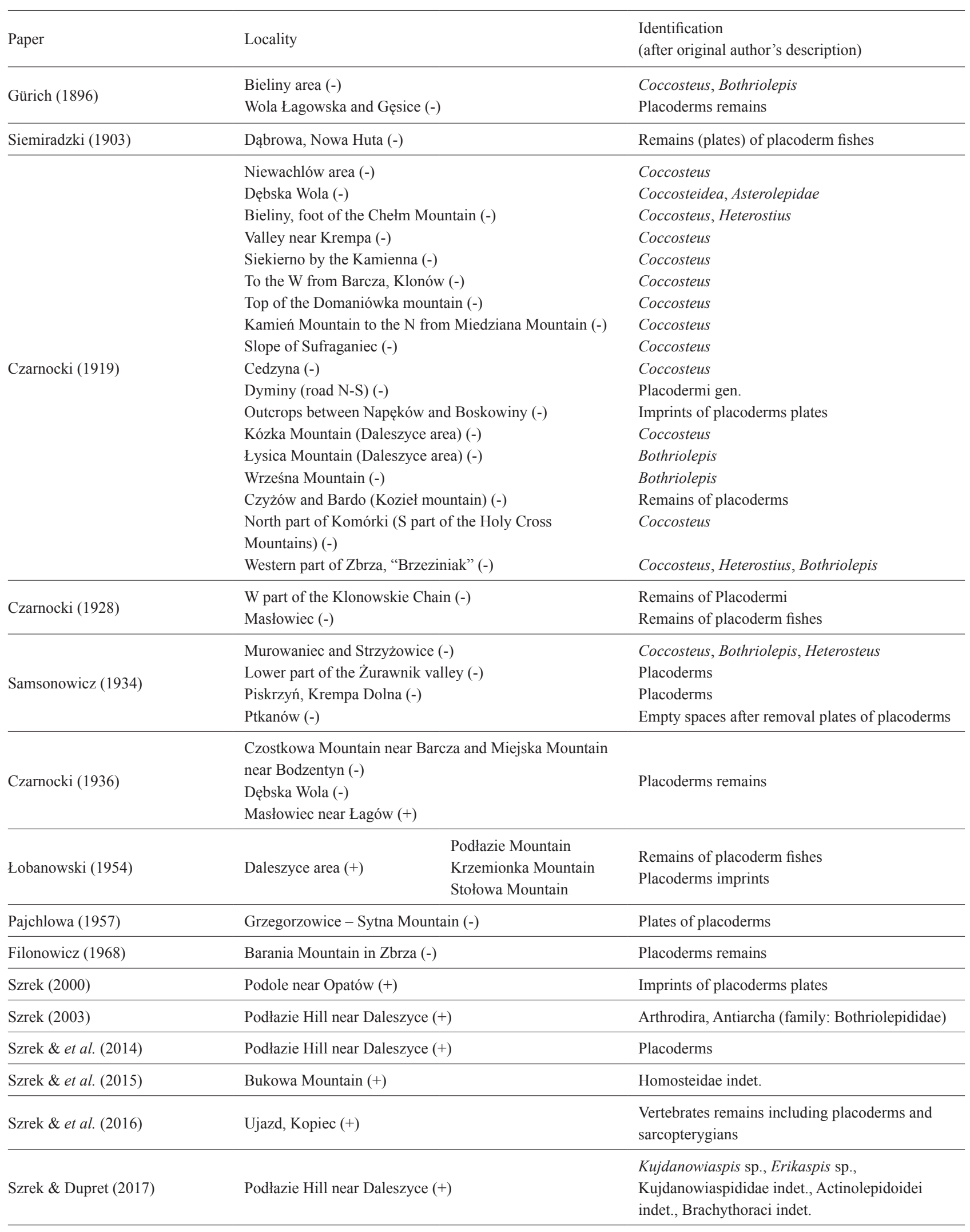


Skały near the Nowa Stupia region, a part of an inferognathal plate (lower jaw) of a brachythoracid arthrodire was found. All of the specimens mentioned above are now under description and will be presented in a separate study.

\section{Upper Devonian (Frasnian and Famennian)}

A detailed study on placoderms from the Late Devonian in the western part of the Holy Cross Mountains was published by Kulczycki $(1956,1957)$ and has been commented on by Ivanov \& Ginter (1997), who exhaustively covered the topic regarding the considerations based on older collections. Only a few specimens described by Kulczycki (1957) have been revised and the sediment samples accompanying the Gyroplacosteus, Malerosteus and Holonema remains were dissolved for conodont biostratigraphy. These analyses allowed to assign these findings to the Palmatolepis falsiovalis Early hassi conodont Zone (Fig. 4).

The localities of Kulczycki's material are not fully accessible for investigations because a natural reserve area has been established in the Kadzielnia and Wietrzna regions. Those localities are partially recultivated and thus are overgrown. About 60 specimens come from the Kadzielnia, Wietrznia, Psie Górki and Ostrówka localities. Recent studies list new material, which comes partially from the same localities where Kulczycki had collected and from new ones, which comprise Famennian specimens from the Płucki and Kowala regions. Płucki (near Łagów) is the richest placoderm site and until now about 100 isolated bones and articulated skeletons have been catalogued and more than 300 still await detailed analysis. Moreover, Płucki and Kowala are still well accessible for investigations and will reveal further material.

According to the latest finds, it is necessary to reexamine two of the comments by Ivanov \& Ginter (1997) about Kulczycki's (1957) contribution. Kulczycki (1957, pl. 13, fig. 1a-c) described elongated bony elements from the Late Devonian of Ostrówka (Gałęzice) assigned provisionally to elasmobranch Alienacanthus as well as other fish remains. It has been noted (Kulczycki 1957) that some of them may have formed the armour of placoderms. Based on new, more complete material, Kulczycki's assumption must be accepted and supplemented with the determination that those elongated elements represent the lower jaw of the undetermined long-snouted placoderm (probably an arthrodire) found by Szrek (2009). The specimen found in 2000 (Fig. 2) in the same locality represents an elongated gently curved element about $30 \mathrm{~cm}$ long. It is a left branch of an inferognathal. The cross section is ellipsoidal with the cross section measuring c. 3 times c. $2 \mathrm{~cm}$. The specimen consists of dermal bone element and reveals a distinct symphysial groove (Fig. 2A). The upper edge of the jaw is covered with toothlike cusps of up to $1 \mathrm{~cm}$ length. The cusps are spaced along the left edge of the jaw in uneven distances $(0.5$ to $1 \mathrm{~cm})$ and are directed backward (Fig. 2A, C-F). The specimen definitely represents a taxon of a large placoderm, which requires more studies on more complete material. The age of this material was dated to the Palmatolepis trachytera conodont Zone. Because of the identical locality and the morphological similarities of Kulczycki's specimen and the new materials, I suppose that all fish fossils from the Ostrówka region share the same age. Similar specimens were illustrated also by Szulczewski et al. (1996, fig. 8f: "fragments of large fish bones") from the same locality. His specimen is partially abraded, but it displays the same morphology and thus probably belongs to the same taxon.

Another issue regards the occurrence of Gyroplacosteus from the Frasnian of the Wietrzna quarry, a taxon which has been identified for the first time by Kulczycki (1957). It was originally described as Operchallosteus and later revised by Obruchev (1964) and Miles (1971) (see Ivanov \& Ginter 1997). Gyroplacosteus panderi was also found in Kowala quarry (Szrek 2006a, 2009) (Fig. 3) and recently, its age has been determined as Palmatolepis crepida to postera conodont Zone (Famennian). Therefore, it is the youngest occurrence of this genus. The remains comprise a left anterior dorso-lateral plate (Fig. 3A, B) and two median dorsal plates (Fig. 3C, D). The plates are ornamented by tubercles fused into sinuous ridges, a very characteristic feature of this genus (Denison 1978).

Ivanov \& Ginter (1997) revised the material described by Kulczycki (1957) and questioned the presence of Antiarchi in the Holy Cross Mountains. Later, Szrek (2004) described the first, quite complete, and exceptionally well preserved placoderm from Poland. The antiarch Bothriolepis jazwicensis from the Famennian (Palmatolepis triangularis conodont Zone) of the Jaźwica quarry is the only verified specimen of this order in the Holy Cross Mountains. Recently, new material of a possible Bothriolepis represented by plates from a pectoral fin and one ventral plate was reported from the lowermost Famennian of the Plucki region (Szrek 2009). Therefore, the pelagic conditions supposed by Ivanov \& Ginter (1997) because of the lack of antiarchs should be re-examined. There are several indications for a highly diversified palaeo-relief during the Late Devonian, where also shallow-water environments (including even subaerial exposure of the seafloor) occurred within this area. Detailed description of the specimens mentioned above will be presented in a separate study.

As stated above, the most fossiliferous locality rich in placoderm material is Płucki in the Rogów region. The 


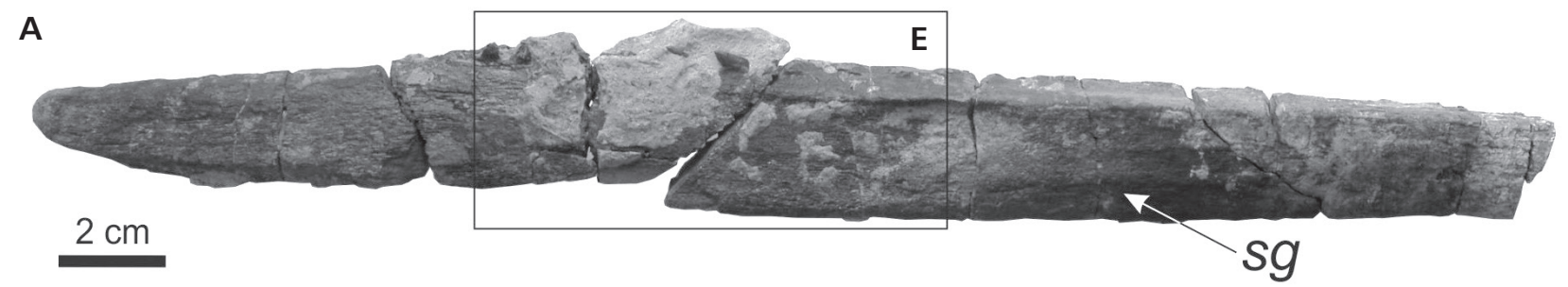

B
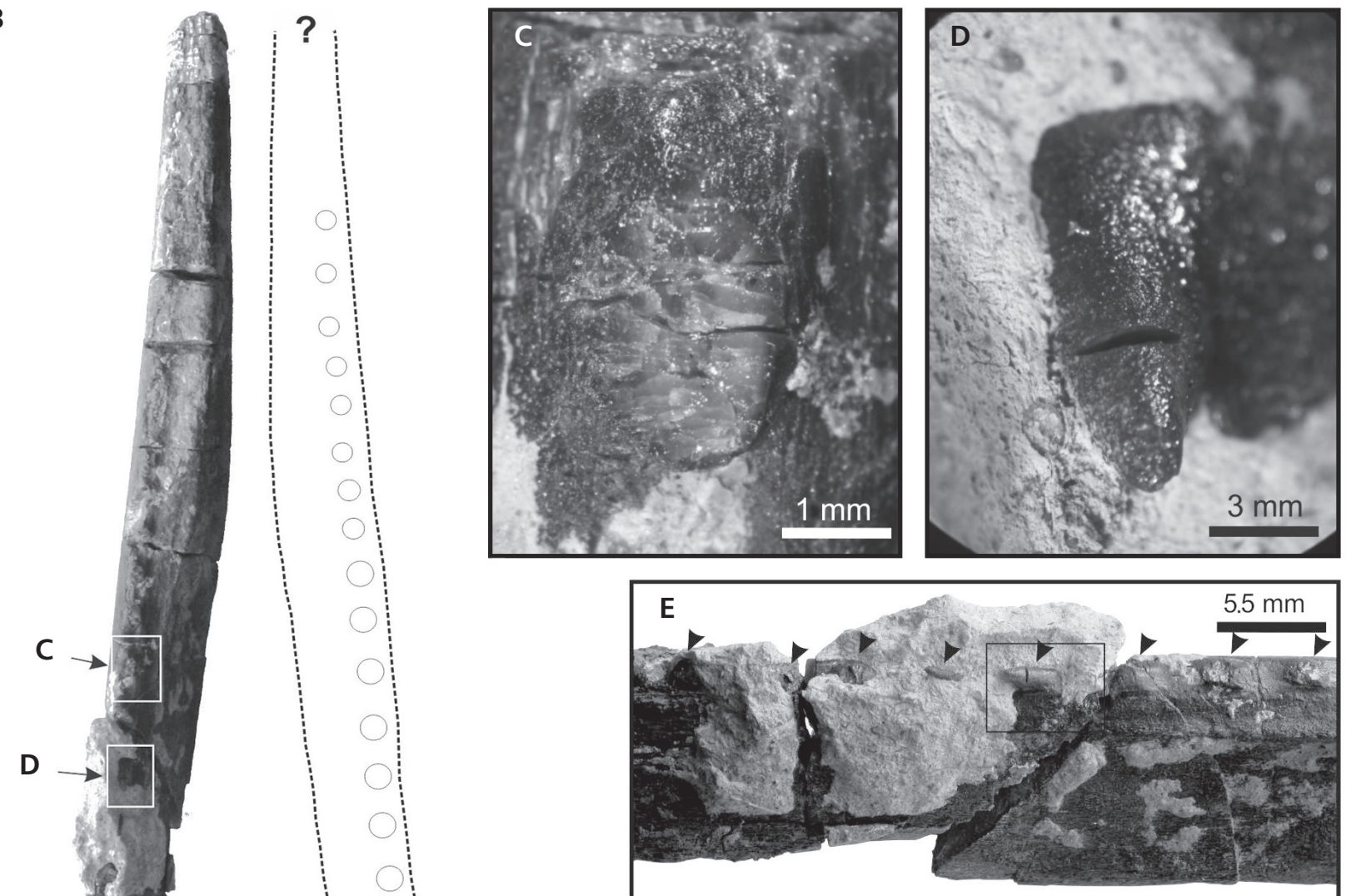

$2 \mathrm{~cm}$

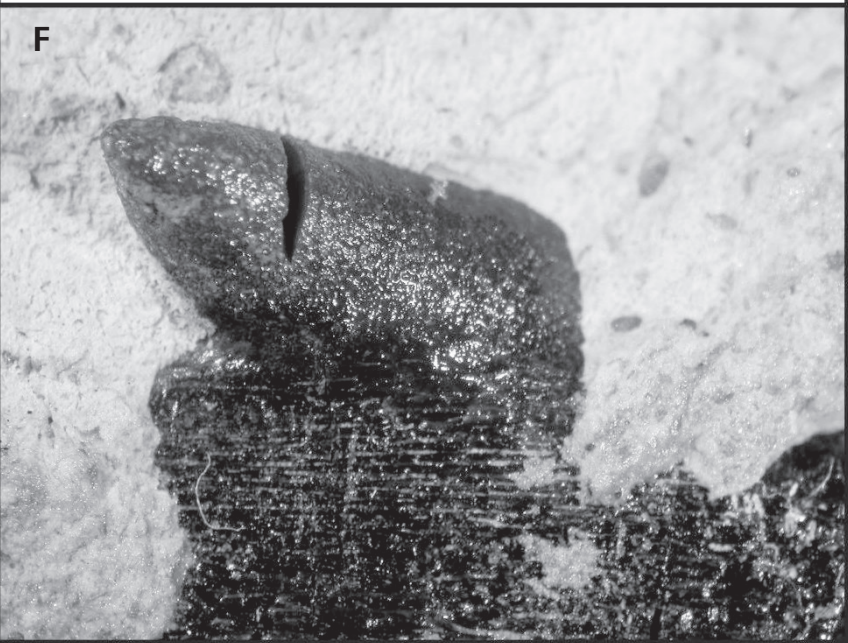

Figure 2. Specimen no. MWG UW ZI/43/0077 from Ostrówka quarry. Left part of inferognathal of an arthodiran placoderm; A - specimen in side (lingual) and dorsal (B) view; C - magnified area on B with a broken cusp; D - magnified area on B with cusp preserved completely; E - magnified area on A with series of cusps on the upper edge (marked with arrows); $\mathrm{F}$ - magnified area on $\mathrm{E}$ with cusp preserved completely in side view. Abbreviation: $s g$ - symphysial grove. 
Phucki assemblage shows similarities to the contemporary assemblage from Bad Wildungen (Germany; based on Gross 1932, 1950; Stensiö 1963; Rücklin 2010). Nine out of the seventeen German taxa described occur in Płucki (Szrek 2008, 2009; Szrek \& Niedźwiedzki 2015): Leptosteus, Microsteus, Rhynchodus, Aspidichthys, Pholidosteus, Brachyosteus, Rhinosteus, Pachyosteus and Bothriolepis (Szrek 2009, Szrek \& Niedźwiedzki 2015). Until now, four of those have been published: Eastmanosteus (Ivanov \& Ginter 1997), Aspidichthys (Dworczak \& Szrek 2016), Dunkleosteus (Szrek \& Wilk 2018), Pachyosteus (Janiszewska et al. 2007). All are uppermost Frasnian in age (Palmatolepis rhenanalinguiformis conodont Zone). The stratigraphic distribution of all of the Upper Devonian placoderms from the Holy Cross Mountains are presented in Fig. 4.

\section{Taphonomy of placoderm fossils}

Four major types of placoderm taphonomic categories were found in the Devonian of the Holy Cross Mountains: 1) isolated, abraded elements; 2) disarticulated skeletons and close associations of bones; 3 ) isolated, wellpreserved elements; and 4) complete, articulated skeletons. In the Early Devonian occurrences, the third type occurs exclusively. The first, second and fourth types occur in the Middle and Late Devonian material (Tab. 2).

The Placoderm Sandstone is a bonebed, which is characterized by a vast richness of vertebrate fossils. It is also characterized by the biggest fragmentation of those fossils: almost no articulated elements have been discovered. The vertebrate remains in the breccia are preserved as natural moulds where the bone tissue had

Table 2. Distribution of taphonomic types of placoderms in the Devonian of the Holy Cross Mountains.

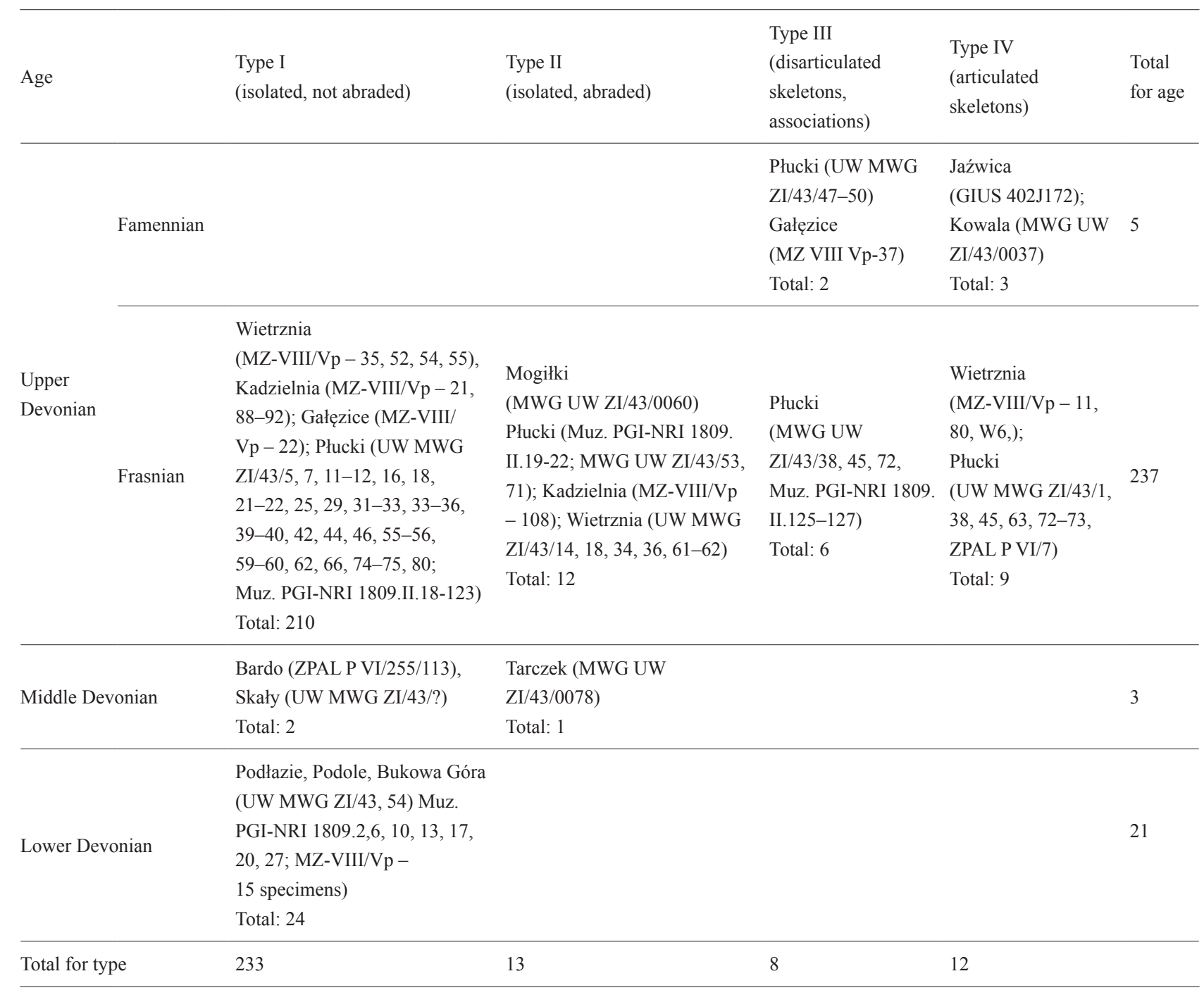


A

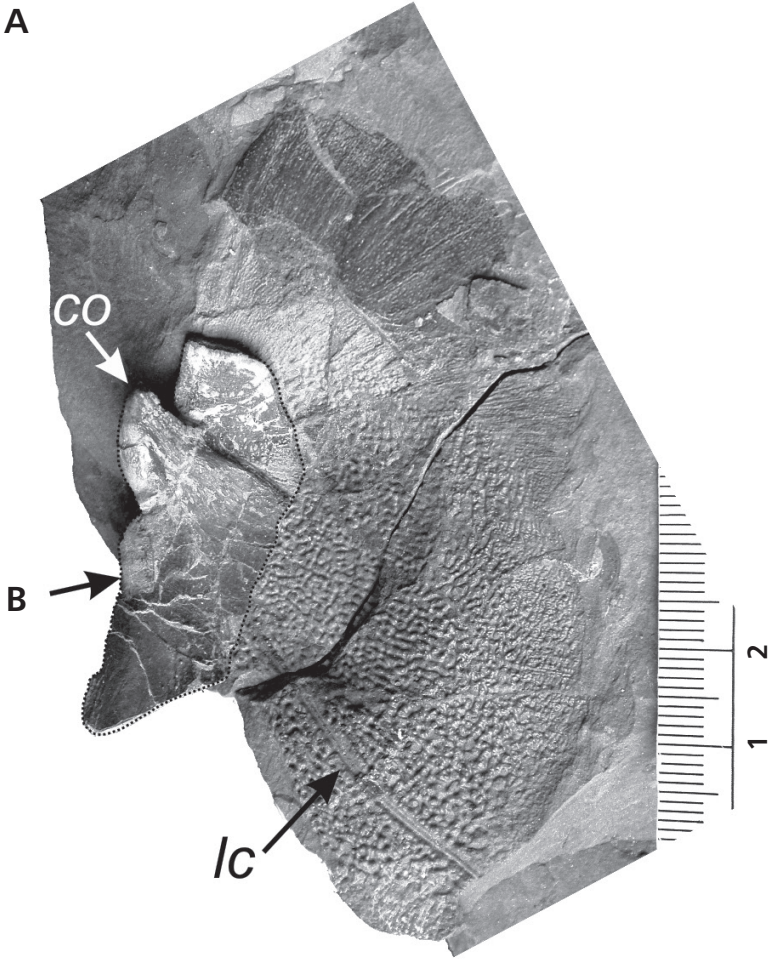

C

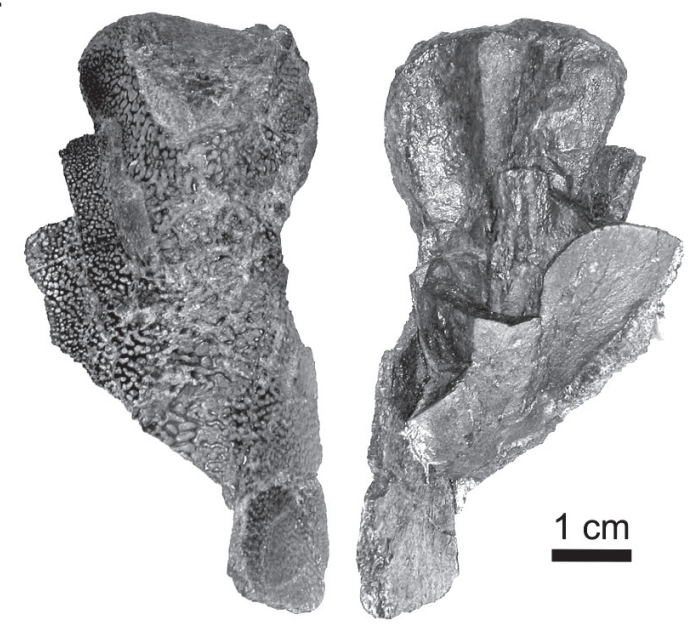

B
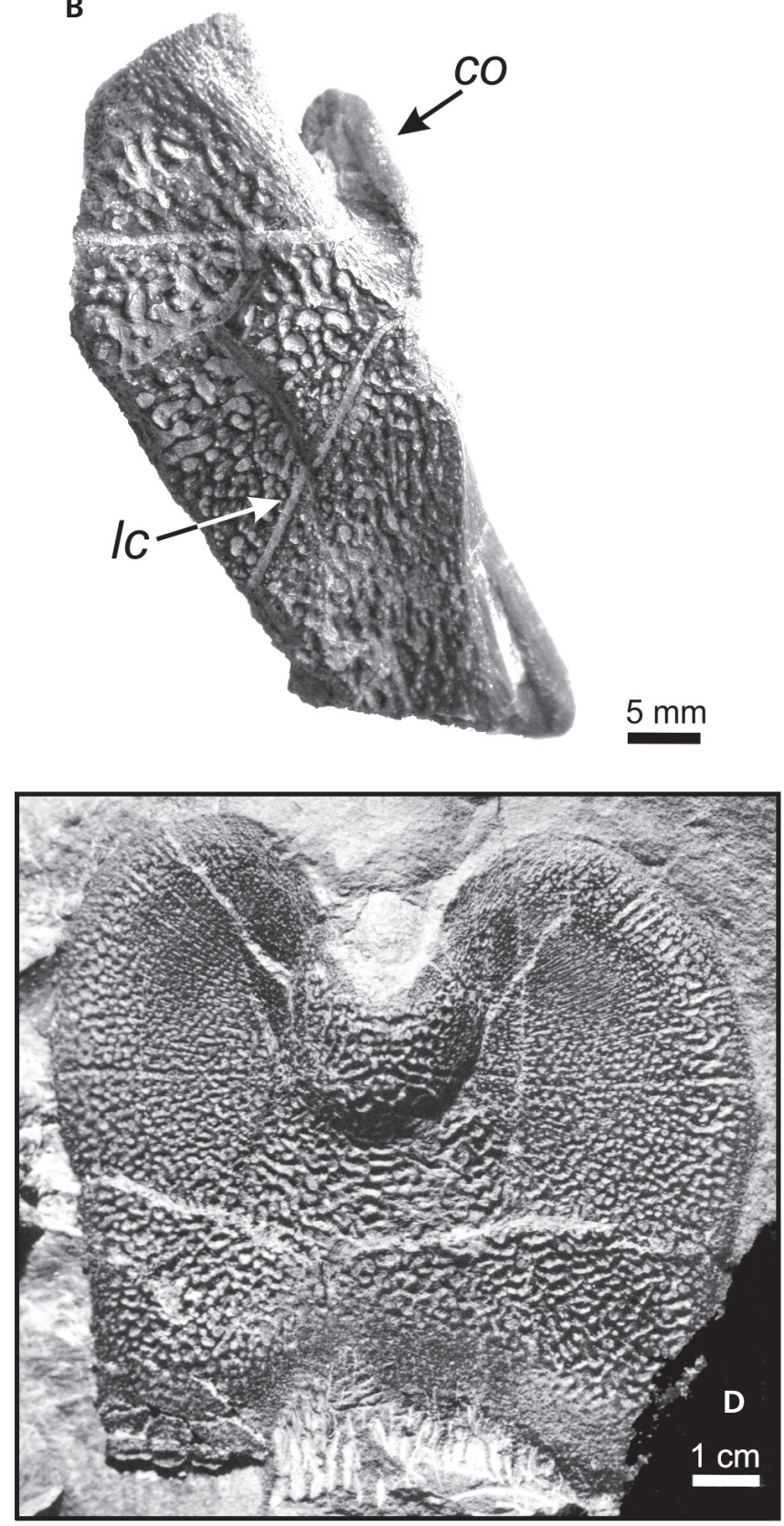

Figure 3. Gyroplacosteus panderi from Kowala quarry; A - specimen no. MWG UW ZI/43/0058, anterior dorso-lateral plate in visceral view; B - part of the specimen no. MWG UW ZI/43/0058, part of a specimen marked with arrow on A; C - specimen no. MWG UW ZI/43/0057, anterior part of the median dorsal plate in external (left) and visceral (right) view; D - unregistered specimen, median dorsal plate in external view. Abbreviations: $c o$ - condyle of anterior dorso-lateral plate; $l c$ - main lateral line canal.

been entirely dissolved. The plates, spines, scales and other skeletal parts have suffered only slight distortion and show anatomical detail including micro-anatomical features, micro-ornamentation, Haver's channels, sensory lines (depending on the vertebrate group) and microsculpture of scale surfaces. All these can be examined on latex or silicon casts. The bone elements are usually broken and their edges are sharp (Szrek et al. 2014, fig. 5; Szrek \& Dupret 2017, figs 3-5), suggesting short transport. The collected elements and the casts of moulds of vertebrate bones are hardly deformed showing the original morphology. The surfaces of the skeletal elements are rarely abraded, although some accumulations contain rare, isolated and highly abraded bone elements. 


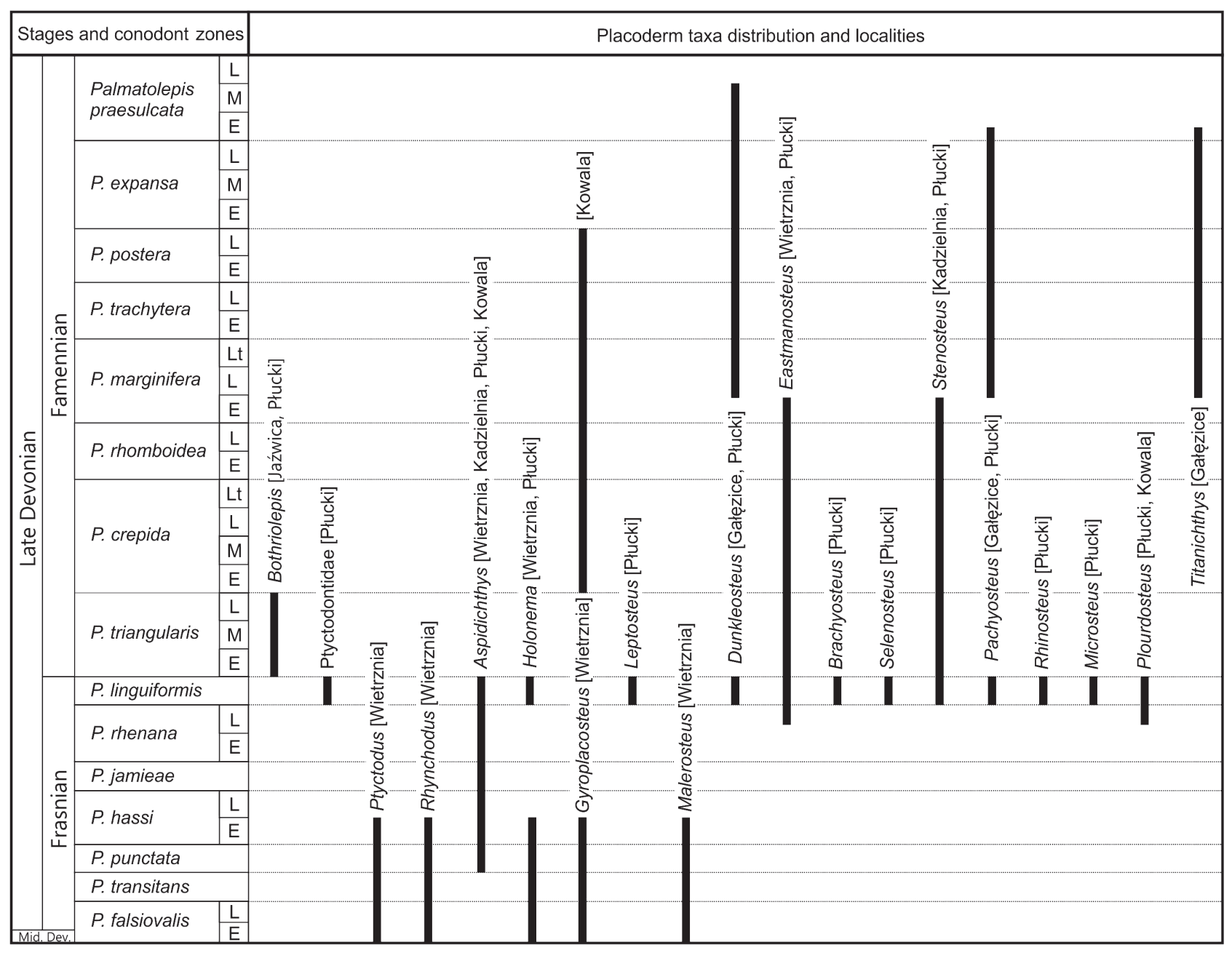

Figure 4. Distribution of placoderms in the Late Devonian of the Holy Cross Mountains.

The mixed nature of this assemblage together with abundant sedimentological indicators for currents and wave action suggest that this bonebed was subjected to storms affecting the coastal area. The Early Devonian vertebrates, including the placoderms, occur very rarely also in the non-sandstone part of the profile, namely in greywacke shales, of the Piskrzyń and Krempa Dolna regions (Samsonowicz 1934, p. 13).

Among the Late Devonian vertebrate assemblages, the first, second, and fourth types of preservation occur. They usually are characterized by a relatively good preservation including even fully articulated skeletons (buried immediately after death), isolated bones that became separated from each other and were abraded during transport as well as associations of well-preserved bones of smaller placoderms that show no traces of long transport (except the influence of posthumous decomposition). The best-preserved fossils (the fourth type) occur in the western part of the region, and comprise interesting specimens such as small individual skulls less than $15 \mathrm{~cm}$ long from the Płucki region. As in other regions, however, such examples represent the exception in the fossil record. The examples of articulated or subarticulated specimens are known from the western part of the area and were discussed by Szrek (2004, 2007b). The first, more common type of preservation contain abraded and fragmented bones of both small and large placoderms (up to $0.6 \mathrm{~m}$ skull length), which were possibly transported before their final burial. They are characterized by broken edges and abraded surfaces and had weathered on the Devonian seafloor (Szrek \& Wilk 2018). In some particular cases, this type of preservation reveals the palaeotectonic history of the area. For example, a large fragment of the median dorsal plate of Dunkleosteus (Fig. $5 \mathrm{~A}-\mathrm{D}$ ) was found recently within the upper Kellwasserlike Horizon in Płucki. It is covered partially by a solid black dolomitic fossiliferous carbonate and occurred in form of a clast that was surrounded by less solid dark brown limestone. The plate with the fossiliferous sediment is abradded and shows features characteristic for transport 
A

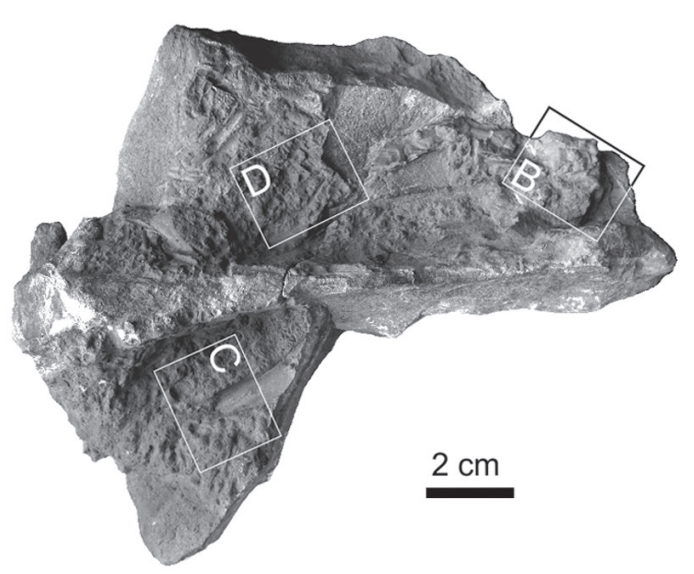

C

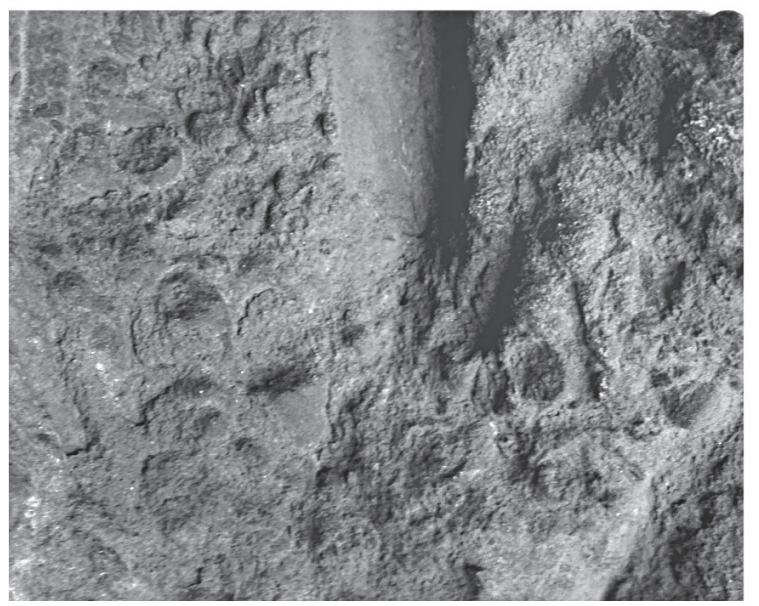

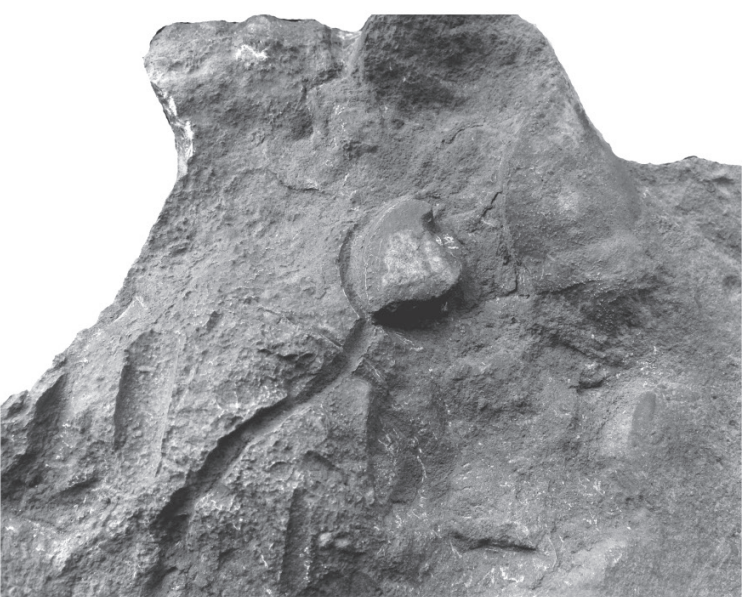

B

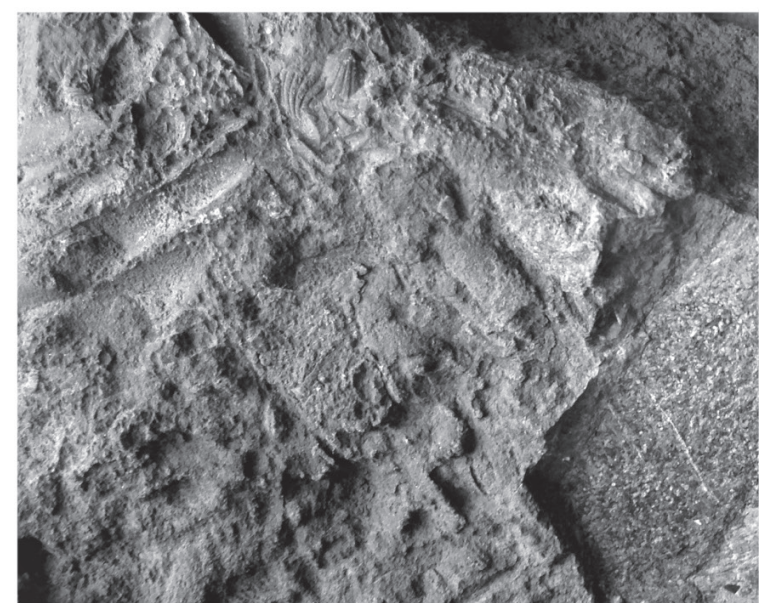

Figure 5. A - median dorsal plate of a big arthrodire (probably Dunkleosteus), with side covered with abraded fossiliferous dolomitic limestone full of orthocone nautiloids and bivalves; the element is prepared from the dark-brown sediment from the Kellwasser-like horizon. Płucki near Łagów; B-D - magnified parts of the specimen (A).

in a form of clast during slump event (Szulczewski 1968, Kazimierczak \& Goldring 1978). This suggests that the main sedimentary area, where Dunkleosteus remains were buried, was temporarily elevated above the place of final burial. This area became then a sediment source, which was eroded and delivered material down the slope in slumps. This explains the preservation and sedimentary setting seen today in the fossiliferous horizon in Płucki. Moreover, it corroborates the validity of the suggested ephemeral emergence episodes of the carbonate platform of the Holy Cross Mountains as described by Skompski \& Szulczewski (2000). These taphonomic observations of the placoderm remains allows the conclusion that it was rather the regional tectonics that controlled water depth and mechanical abrasion during slumping and thereby bone preservation than the chemical influence of sea water.

The placoderms probably played an important role in the local ecosystem even after their death. In many cases, their dermal plates show traces of the activity of epibenthic organisms. Such examples come mainly from the Famennian when almost the entire area of the Holy Cross Mountains was dominated by pelagic sedimentation and placoderm plates might have been the only or almost only hard elements on the sea-floor (Seilacher 1982).

A well-known case regarding epibionts on placoderm bones comes from Australia (White 1978) and is represented by a tabulate coral colony of Aulopora, which overgrew the head shield of Burrinjucosteus symmetricus. In the Holy Cross Mountains, epibionts were reported from the Famennian of Kowala and Wietrzna quarries. The few specimens comprise a median-dorsal plate of brachthoracid arthrodire and an unidentified, probably ventral plate showing scavenging traces (Fig. 6A, B). The traces are dendritiform and only about 0.5 to $1 \mathrm{~mm}$ deep. Their infills are comprised of limestone and confirm their Devonian age. The potential trace-maker might have been a representative of scavenging bryozoans provisionally attributed to hederellids (Kiepura 1973, González-Mora et al. 2018). 
Several bones of large arthrodires from Kowala quarry are covered on one side with sediment chock-a-block with moulted exoskeletons of phacopid trilobites (Fig. 7). The explanation for such a case is probably that the bones of placoderms lying on the soft substrate of the sea floor might have been utilized by those arthropods as a shelter during ecdysis (see Daley \& Drage 2015). However, current-alignmment of trilobite exuviae behind the bones cannot be excluded.

\section{Discussion}

The placoderm diversity in the Holy Cross Mountains, in spite of their uneven abundance and occurrence in space and time, reflect important trends in biological evolution as well as changes in the global marine ecosystems.

The Early Devonian placoderm assemblages from the Holy Cross Mountains are not rich and diversified. They reveal differences in taxonomic composition to neighbouring regions. Homosteid material from Poland represents a transitional position between the Rhineland, Germany (Gross 1942) and the West Siberian Platform in Perevozinskoe, Russia (Krasnov \& Kurik 1982). By contrast, the "placoderm sandstone" assemblage is more similar to the Podolian fauna (Szrek \& Dupret 2017). Since the "placoderm sandstone" assemblage differs at species level with more derived taxa, Szrek \& Dupret (2017) concluded that the Holy Cross Mountains served as a potential refuge for older Early Devonian Kujdanowiaspis assemblages from Podolia and maybe even for those found in Spain (Dupret et al. 2011, Szrek \& Dupret 2017). Placoderms from the Early Devonian of the Holy Cross Mountains are represented by six taxa but only two genera, which might be distinguished in the entire assemblage. The reason for this low diversity is the fragmentary state of fossil preservation, which does not allow species-level identification. Information about the stratigraphic distribution of placoderms in the Early Devonian of the Holy Cross Mountains is very limited. The age of placoderms from the "placoderm sandstone" cannot be precisely determined because of the lack of stratigraphic markers. However, according to Tarnowska (1976) and palynological data from boreholes in the vicinity, it is most likely that the age of the placoderms in the Łysogóry and Kielce regions is late Emsian (Zagórze "formation" for Łysogóry and Winna "formation" for Kielce region; Fijałkowska-Mader \& Malec 2011, 2018; Szrek et al. 2014; Szrek \& Dupret 2017).

The Middle Devonian placoderms are represented by relatively poorly preserved material. These specimens show no trends in their diversity or geographical distribution, thus they will not be further discussed herein.

The Late Devonian placoderms are the best dated because of the abundance of associated conodonts. Late Devonian vertebrate distribution in the Holy Cross Mountains was examined by Gorizdro-Kulczycka (1934, 1949), Kulczycki (1957), Liszkowski \& Racki (1993), as well as Ivanov \& Ginter (1997). It can be generally concluded that the placoderms were highly environmentally tolerant. Also, the Late Devonian assemblages show a mixed character reminiscent of other well recognized Laurussian (Rhenish Massif, East European Platform, North America - Cleveland Shale) and Gondwanan assemblages (Morocco, Iran, Australia). As Ivanov \& Ginter (1997) noticed, many forms, which have been found together in the Holy Cross Mountains, coexist in other regions as well. This was revised and partly confirmed by Szrek (2004, 2008, 2009). In some respects, the Late Devonian assemblage resembles that from the Late Devonian Gogo Formation Lagerstätte of Western Australia. The Polish material is not as well preserved as that from the Gogo Formation. Nevertheless, the taxonomic composition of the Polish placoderm assemblage and that from Australia reveal intriguing similarities. According to the general analyses of the Gogo fauna by Long \& Trinajstic (2010), one antiarch, three ptyctodonts, and twenty-five arthrodire species are already described. In the Holy Cross Mountains, there is one antiarch, at least two ptyctodonts and twenty arthrodire species. The reason for this similarity and the maybe slightly higher diversity in Australia may be explained by the stable reef-influenced environment. This environment lasted longer in Gogo (Playford 1980) than in the Holy Cross Mountains, where regional tectonic activity caused regional sea-level changes (e.g. Szulczewski 1971, Racki 1993). In turn, this explains the lower diversity and worse fossil preservation of the Polish material in comparison with Australia. In addition, the relative abundances of placoderm lifestyles are similar in both regions. Small nektonic and durophagous predators (e.g. ptyctodonts) dominate while mud-dwellers (antiarchs) and large nektonic predators (Eastmanosteus, Dunkleosteus) are in the minority. More detailed analyses of the entire vertebrate fauna comprising agnathans, acanthodians and osteichthyans from the Late Devonian of the Holy Cross Mountains would be valuable and could help to shed more light on this ecosystem and its foodwebs.

The available vertebrate data is not sufficient yet to confidently assess how deeply the Frasnian-Famennian biotic crisis impacted the placoderm fauna in the Holy Cross Mountains. The exclusively durophagous ptyctodonts do not cross the F-F boundary, which may be interpreted as a consequence of the reef collapse at that time (Copper 1994; McGhee 2013, 2014). However, in the Holy Cross Mountains, the reef-related environments disappeared long before the end of the Frasnian (Szulczewski 1971, Racki 1993, Skompski \& Szulczewski 
A

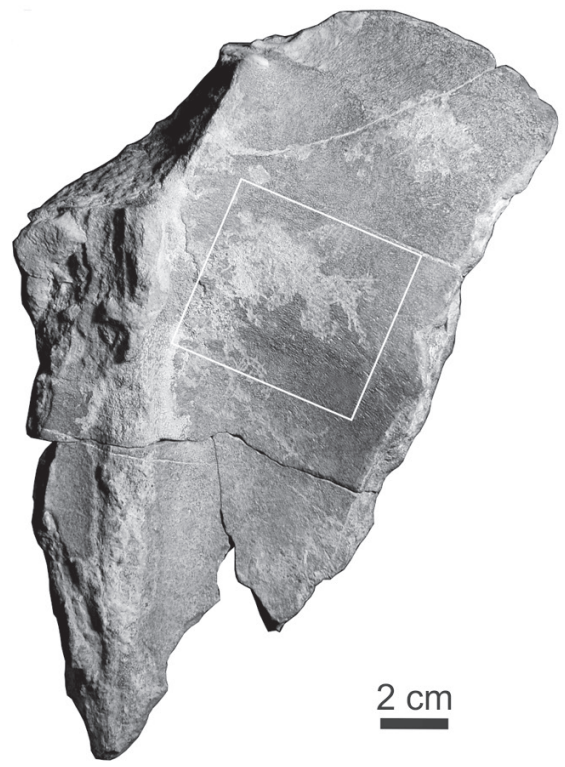

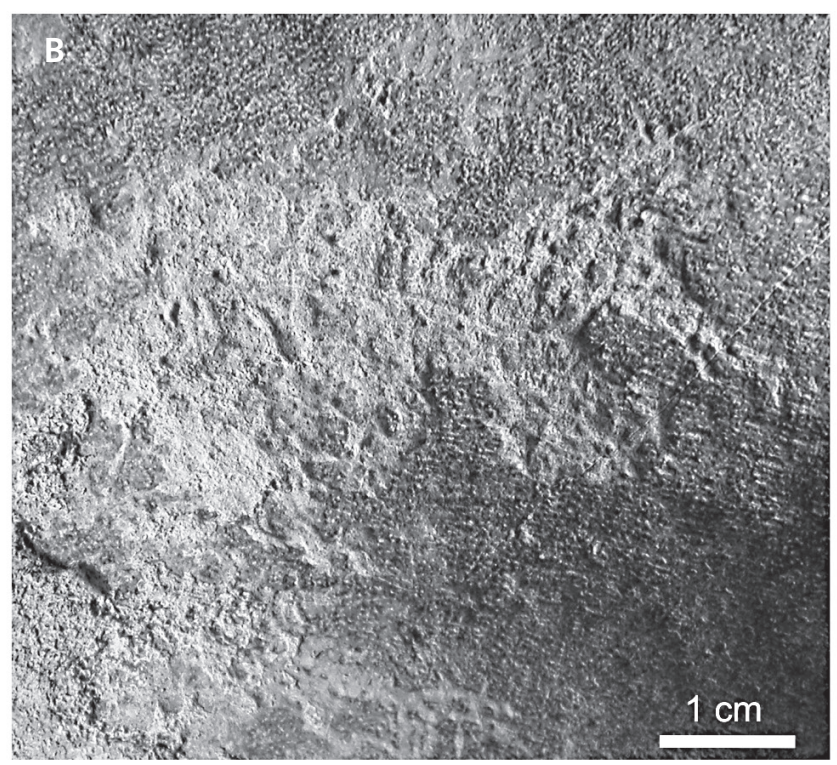

Figure 6. Median dorsal plate of an arthrodiran placoderm in visceral view (A) with bryozoan etching traces in the magnified area (B). Kowala quarry.

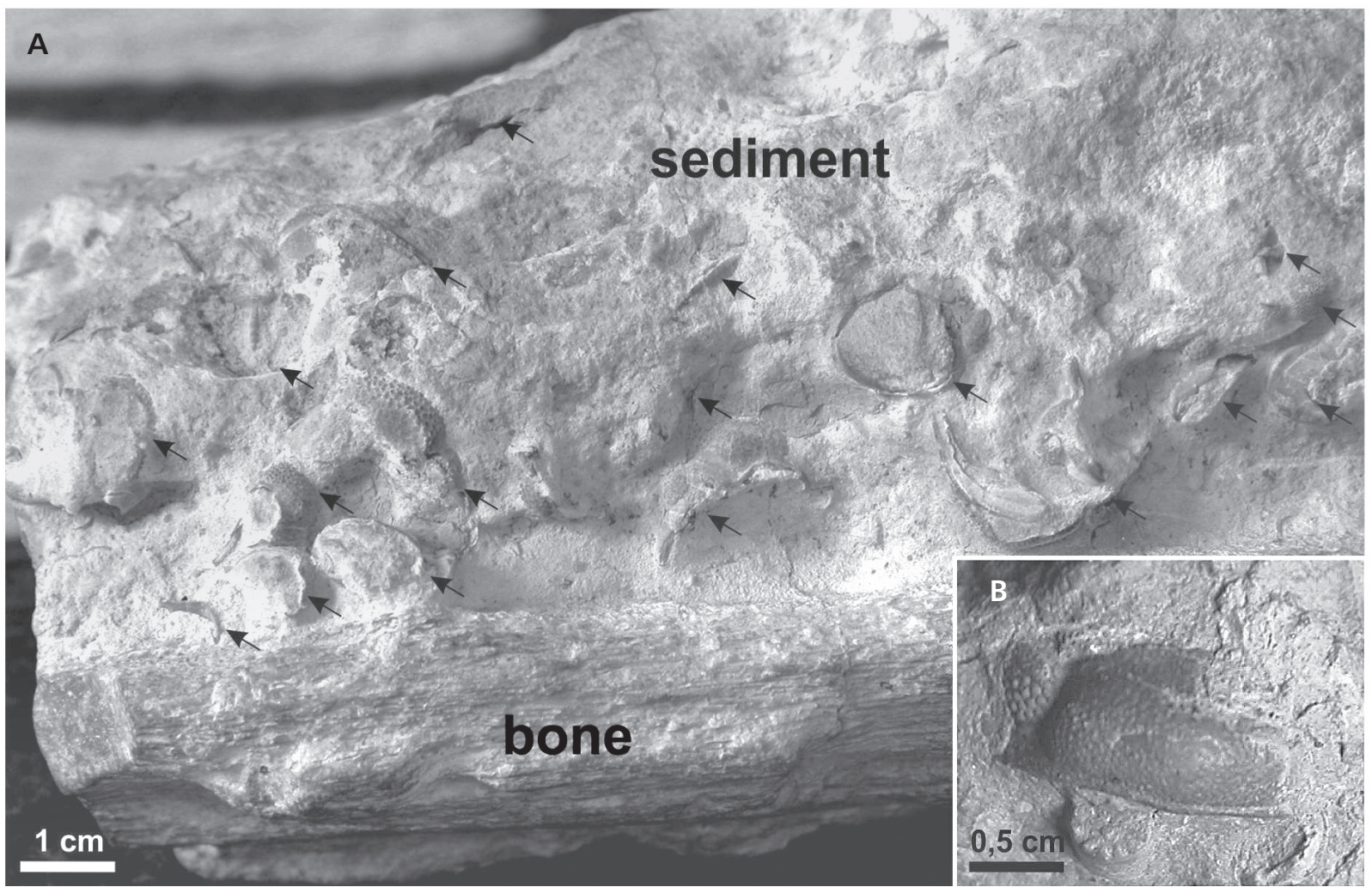

Figure 7. Specimen no. MWG UW ZI/43/0070 from Kowala quarry; A - part of an arthrodiran placoderm' bone covered with limestone rich in trilobites marked with arrows and magnified in B.

2000) and the last occurrence of ptyctodonts were dated to the youngest part of this stage (Fig. 4). Indeed, several taxa are restricted to the latest Frasnian (Palmatolepis linguiformis conodont Zone) in the stratigraphic range of Plourdosteus, Microsteus, Rhinosteus, Selenosteus, Brachyosteus and Leptosteus. Nevertheless, the seeming intensity of this extinction may be an effect of the extraordinary richness of fossils in the "Kellwasser" 
Horizon in Płucki where these placoderms were found (Lagerstätten-effect). In some respects, the stratigraphic range of particular taxa such as Pachyosteus, Stenosteus, Eastmanosteus and Dunkleosteus is wider than in other localities. A good example of the unexpected survivor of the F-F boundary is the holonematid Gyroplacosteus (Fig. 3), which was discovered in the Famennian of Kowala quarry (Palmatolepis crepida-P. postera conodont Zones). Previously, holonematids were not known to have survived the Frasnian-Famennian biotic crisis (Denison 1978).

The general change in placoderm assemblages through the Devonian reveal the replacement of Early Devonian demersal placoderms by a Late Devonian diversified nektonic-dominated placoderm assemblage. This was influenced by the palaeoenvironmental changes in the entire area of the Holy Cross Mountains and the geo-tectonic conditions, which influenced the regional evolution of marine ecosystems. By contrast, the appearance of more active nektonic predators match the global tendency described by Klug et al. (2010), which is especially evident in the Frasnian period where the number of taxa and specimens increased markedly. A similar correlation of placoderm diversity with the Devonian Nekton Revolution was discovered by Vaškaninová \& Kraft (2014) in the Prague Basin where the Early to Middle Devonian sedimentary development reflects rather stable conditions with a rich palaeobiodiversity.

\section{Conclusions}

The distribution, preservation and abundance of placoderm remains in the Holy Cross Mountains is very uneven in space and time, which partially reflects the low number of outcrops. This applies especially to the Middle Devonian where only a few specimens have been found over the past century.

The spatial and stratigraphic distribution as well as the state of preservation of placoderms mostly correlates with the complicated facies evolution of the entire area. I thus suggest a close relationship between the states of preservation, taxonomic occurrences and sedimentary environments (reflecting both palaeoecology and taphonomic pathways).

The taxonomic distribution of placoderms in space and time within the Devonian of the Holy Cross Mountains is well correlated with the Devonian Nekton Revolution. Nevertheless, it is also strongly influenced by local synsedimentary tectonics that affected the carbonate platform. In the Holy Cross Mountains, the tectonic trends influenced faunal changes more than the global anoxia, which probably asphyxiated much of the area that laid below the reef-tolerance level.

\section{Acknowledgements}

Christian Klug and Martin Rücklin are appreciated for many precious remarks and kind revision of the earlier versions of the manuscript. The author was funded by the Polish National Science Center (project number 2016/23/B/ST10/03262 granted to Michał Ginter).

\section{References}

Averbuch, O., Tribovillard, N., Devleeschouwer, X., Riquier, L., Mistiaen, B. \& Van Vliet-Lanoe, B. 2005. Mountain building-enhanced continental weathering and organic carbon burial as major causes for climatic cooling at the FrasnianFamennian boundary (c. $376 \mathrm{Ma}$ )? Terra Nova 17, 25-34. DOI 10.1111/j.1365-3121.2004.00580.x

BliecK, A. 1980. Le genre Rhinopteraspis Jaekel (Vertébrés, Hétérostracés) du Dévonien inférieur: systématique, morphologie, répartition. Bull. Mus. natn. Hist. Natur. $4^{e}$ série, 2, section C, 1, 25-47.

Copper, P. 1994. Ancient reef ecosystems expansion and collapse. Coral Reefs 13, 3-11.

DOI 10.1007/BF00426428

Czarnocki, J. 1919. Stratigraphy and tectonics of the Holy Cross Mountains. Prace Towarzystwa Naukowego Warszawskiego 28, 1-172.

Czarnocki, J. 1928. Przegląd stratygrafii famenu i karbonu dolnego (kulmu), w zachodniej i środkowej cześći Gór Świętokrzyskich. Posiedzenia Naukowe Państwowego Instytutu Geologicznego 21, 55-59.

Czarnocki, J. 1936. Überblick der Stratigraphie und Palaeogeographie des Unterdevons im polnischen Mittelgebirge. Sprawozdania Państwowego Instytutu Geologicznego 7, 129-200.

Daley, A.C. \& Drage, H.B. 2015. The fossil record of ecdysis, and trends in the moulting behaviour of trilobites. Arthropod Structure \& Development 45, 71-96.

DOI 10.1016/j.asd.2015.09.004

Denison, R.H. 1978. Placodermi, 1-128. In Schultze, H.-P. (ed.) Handbook of Paleoichthyology Vol. 2. Gustav Fischer, Stuttgart-New York.

Domeier, M. \& Torsvik, T.H. 2014. Plate tectonic in the late Paleozoic. Geoscience Frontiers 5, 303-350.

DOI 10.1016/j.gsf.2014.01.002

Dupret, V., Carls, P., Martínez-Pérez, C., \& Botella, H. 2011. First Perigondwanan record of actinolepids (Vertebrata: Placodermi: Arthrodira) from the Lochkovian (Early Devonian) of Spain and its palaeobiogeographic significance. Palaeogeography, Palaeoclimatology, Palaeoecology 310, 273-282. DOI 10.1016/j.palaeo.2011.07.019

Dworczak, P. \& SzREK, P. 2016. The Late Devonian placoderm Aspidichthys Newberry, 1873 from the Holy Cross Mountains, Poland. Fossil Record 20, 9-19.

DOI 10.5194/fr-20-9-2016

Fijalkowska-Mader, A. \& Malec, J. 2011. Biostratigraphy of 
the Emsian to Eifelian in the Holy Cross Mountains (Poland). Geological Quarterly 55, 109-138.

Fijalkowska-Mader, A. \& Malec, J. 2018. Age of the Lower Devonian tuffite horizon from Barcza (Holy Cross Mountains, S Poland). Przegląd Geologiczny 66, 578-584. DOI $10.7306 / 2018.8$

Filonowicz, P. 1968. Descriptions for the detailed geological map of Poland, Kielce sheet. 100 pp. Wydawnictwa Geologiczne, Warszawa.

González-Mora, S., Wyse-Jackson, P.N., Torres-Martínez, M.A., Buitrón-Sánchez, B.E., Barragán, R. \& SourTovar, F. 2018. Hederella carbonaria Condra \& Elias, 1944 from the Roadian (middle Permian) of Mexico. Bulletin of Geosciences 93, 457-461. DOI 10.3140/bull.geosci.1716

Gorizdro-Kulczycka, Z. 1934. Sur les Ptyctodontida du dévonien supérieur du Massif de S-te Croix. Travaux du Service Géologique de Pologne 3, 1-17.

Gorizdro-KulczycKa, Z. 1949. Wykopaliska na Kadzielni i pewne zagadnienia ichtiologiczne. Wiadomości Muzeum Ziemi 4, 173-186.

Gorizdro-KulczycKa, Z. 1950. Les Dipneustes dévoniens du Massif de S-te Croix. Acta Geologica Polonica 1, 53-82.

Gorzelak, P., Rakowicz, Ł., Salamon, M.A. \& Szrek, P. 2010. Inferred placoderm bite marks on Devonian crinoids from Poland. Neues Jahrbuch für Geologie und Paläontologie Abhandlungen 259(1), 105-112.

DOI 10.1127/0077-7749/2010/0111

Gross, W. 1932. Die Arthrodira Wildungens. Geologische und Palaeontologische Abhandlungen 19, 5-61.

Gross, W. 1942. Die Fischfaunen des baltischem Devons und ihre biostratigraphische Bedeutung. Korrespondenzblatt des Naturforscher-Vereins zu Riga 34, 373-436.

Gross, W. 1950. Die paläontologische und stratigraphische Bedeutung der Wirbeltierfaunen des Old Reds und der narinen altpaläozoischen Schichten. Abhandlungen der Deutschen Akademie der Wissenschaften zu Berlin, Mathematischnaturwissenschaftliche Klasse 1, 1-130.

GüRICH, G. 1896. Das Paläozoicum im Polnische Mittelgebirge. Verhandlungen der Russischen-Kaiserlichen Mineralogischen Gesellscheft zu St-Petersburg 2(32), 1-539.

Ivanov, A. \& Ginter, M. 1997. Comments on the Late Devonian placoderms from the Holy Cross Mountains (Poland). Acta Palaeontologica Polonica 42, 413-426.

Janiszewska, K., Szrek, P. \& Woroncowa-Marcinowska, T. 2007. Zapis zdarzeń biotycznych na pograniczu frańskofameńskim w Płuckach koło Łagowa, 63-66. In ŻYLiŃsKA, A. (ed.) Granice Paleontologii, XX Konferencja Paleobiologów i Biostratygrafów PTG, Św. Katarzyna pod Eysica, 10-13 września 2007.

KaźmierczaK, J. \& Goldring, R. 1978. Subtidal flat-pebble conglomerate from the Upper Devonian of Poland: a multiprovenant high-energy product. Geological Magazine 115, 359-366. DOI 10.1017/S0016756800037377

Kiepura, M. 1973. Devonian bryozoans of the Holy Cross Mountains, Poland. Part II. Cyclostomata and Cystoporata. Acta Palaeontologica Polonica 18, 325-400.

Klug, C., Kröger, B., Kiessling, W., Mullins, G.L., Servais, T.,
FrÝdA, J., Korn, D. \& Turner, S. 2010. The Devonian nekton revolution. Lethaia 43, 465-477.

DOI 10.1111/j.1502-3931.2009.00206.x

KontKiewicz, S. 1882. Sprawozdanie z badań geologicznych dokonanych w $1880 \mathrm{w}$ południowej części guberni kieleckiej. Pamiętnik Fizjograficzny 2, 2-6.

Kosmowska-Ceranowicz, B. 1973. The scientific and social activities of Stanisław Kontkiewicz Sr. and his son Stanisław Kontkiewicz Jr. and their geologic collections. Travaux $d u$ musée de la terre 21, 29-161.

KowALCZEWSKI, Z. 1971. Main geological problems of the Lower Devonian in the Świętokrzyskie Mts. Geological Quarterly 15, 263-283.

Krasnov, V.N. \& Kurik, E. 1982. First find of fossil fish in limestones of the Tashtyp Formation of the South-Minusinsk Depression, 47-52. In Yuferev, O.V. (ed.) Stratigraphy and Palaeontology of the Devonian and Carboniferous. Transactions of the Institute of Geology and Geophysics, Academy of Sciences of the USSR, Siberian Branch. [in Russian]

Kulczycka, Z. 1933. Ptyktodonty górno-dewońskie z gór Świętokrzyskich. Posiedzenia Naukowe Państwowego Instytutu Geologicznego 36, p. 84.

KulCZYCKI, J. 1956. On the parasphenoid of the brachythoraci. Acta Palaeontologica Polonica 1, 103-114.

Kulczycki, J. 1957. Upper Devonian fishes from the Holy Cross Mountains. Acta Palaeontologica Polonica 2, 285-380.

Kulczycki, J. 1960. Porolepis (Crossopterygii) from the Lower Devonian of the Holy Cross Mountains. Acta Palaeontologica Polonica 5, 65-103.

Liszkowski, J. \& RAcki, G. 1993. Ichthyolits and deepening events in the Devonian carbonate platform of the Holy Cross Mountains. Acta Palaeontologica Polonica 37, 407-426.

Łobanowski, H. 1954. Daleszyce area geology field notes, unpublished. Archive of the Polish Geological InstituteNational Research Institute.

Long, J. \& Trinasstic, K. 2018. A review of recent discoveries of exceptionally preserved fossil fishes from the Gogo sites (Late Devonian, Western Australia). Earth and Environmental Science Transactions of the Royal Society of Edinburgh 2018, 1-7. DOI 10.1017/S1755691018000178

LyelL, C. 1885. Student's elements of geology. $4^{\text {th }}$ ed. $621 \mathrm{pp}$. John Murray, Albemarle Street, London.

McCoy, F. 1848. On some new fossil fish of the Carboniferous period. Annals and Magazine of Natural History 2, 1-10. DOI 10.1080/03745485809496133

McGhee, G.R. JR. 2013. When the Invasion of land failed. The Legacy of the Devonian Extinctions. 317 pp. Columbia University Press, New York.

DOI 10.7312/columbia/9780231160575.001.0001

McGhee, G.R. JR. 2014. The Late Devonian (Frasnian/Famenian) mass extinction: a proposed test of the glaciation hypothesis. Geological Quarterly 58, 263-268. DOI 10.7306/gq.1143

Michalski, A. 1884. Badania geologiczne dokonane w r. 1883 w północno-wschodniej części gub. Kieleckiej. Pamiętnik Fizjograficzny 4, 12-19.

Miles, R.S. 1971. The Holonematidae (placoderm fishes): a review based on new specimens of Holonema from the 
Upper Devonian of Western Australia. Philosophical Transactions of the Royal Society of London 263 B, 101-234. DOI 10.1098/rstb.1971.0111

Nawrocki, J., Nawrocka-Pańczyk, M. \& Szrek, P. in press. Magmatic activity at the Silurian/Devonian boundary in the Brunovistulia and Małopolska terranes (S Poland): possible link with the onset of the Rheic Ocean closure. Geological Magazine, 1-15. DOI 10.1017/S0016756819000384

Neumayr, M. 1895. Erdgeschichte. Allgemeine Geologie. 693 pp. Bibliographisches Institut. Leipzig, Wien.

Obruchev, D. 1964. Class Placodermi, 118-172. In Obruchev, D. (ed.) Osnovy Paleontologii 11. Nauka, Moskva.

Pajchlowa, M. 1957. Dewon w profilu Grzegorzowice-Skały. Biuletyn Państwowego Instytutu Geologicznego 122, 145-241.

PawŁowska, K. 1954. Nowe dane o paleozoiku na północ od Sandomierza. Komunikat wstępny. Przegląd Geologiczny $2,461-462$.

PAWŁOWSKA, K. 1961. W sprawie wieku warstw bostowskich w związku z problemem granicy pomiędzy sylurem i dewonem w Górach Świętokrzyskich. Geological Quarterly 5, 526-538.

Playford, P.E. 1980. The Devonian "Great Barrier Reef" of the Canning Basin, Western Australia. American Association of Petroleum Geologists Bulletin 64, 814-840.

DOI 10.1306/2F9193BE-16CE-11D7-8645000102C1865D

RACKI, G. 1993. Evolution of the bank to reef complex in the Devonian of the Holy Cross Mountains. Acta Palaeontologica Polonica 37, 87-182.

Racki, G., Racka, M., Matyja, H. \& Devleeschouwer, X. 2002. The Frasnian/Famennian boundary interval in the South Polish-Moravian shelf basins: integrated event-stratigraphical approach. Palaeogeography, Palaeoclimatology, Palaeoecology 181, 251-297. DOI 10.1016/S0031-0182(01)00481-3

RADWAŃSKi, A. \& Roniewicz, P. 1962. Submarine slumping in the Famennian of the Holy Cross Mountains (central Poland). Acta Geologica Polonica 12, 295-304.

RüCKLIN, M. 2010. A new Frasnian placoderm assemblage from the eastern Anti-Atlas, Morocco, and its palaeobiogeographical implications. Palaeoworld 19, 87-93. DOI 10.1016/j.palwor.2009.11.002

SAmsonowicz, J. 1934. Objaśnienie arkusza Opatów. Ogólna mapa geologiczna Polski w skali 1:100 000. Wydanie Państwowego Instytutu Geologicznego 1, 1-117.

SeIlacher, A. 1982. Ammonite shells as habitats in the Posidonia Shales of Holzmaden - floats or benthic islands? Neues Jahrbuch für Geologie und Paläontologie, Monatshefte 2, 98-114.

SiemiradzKI, J. 1903. Geologia ziem polskich, tom I-formacye starsze do jurajskiej włacznie. 106-178 pp. Muzeum Imenia Dzieduszyckich, Lwów.

Skompski, S. \& SzULCZEwski, M. 2000. Lofer-type cyclothems in the Upper Devonian of the Holy Cross Mts. (central Poland). Acta Geologica Polonica 50, 393-406.

Sobolev, D. 1912. O verkhnem neodevone Lagowa. Izvestiya Varshavskogo Politekhnicheskogo Instituta 3, 1-32. [in Russian]
STEnsiö, E. 1963. Anatomical studies on the arthrodiran head. Part I. Kunglia Svenska Vetenskapsakademiens Handlingar 9, 1-419.

Szrek, P. 2000. Ryby dewońskie Gór Świętokrzyskich. Posiedzenia Naukowe Państwowego Instytutu Geologicznego 56, 106-108.

SzReK, P. 2003. Nowe dane na temat fauny kręgowców w „piaskowcach plakodermowych" z rejonu Daleszyc (Góry Świętokrzyskie). Przegląd Geologiczny 51, 409-411.

SzReK, P. 2004. The first articulated antiarch (Vertebrata, Placodermi) from the Upper Devonian of the Holy Cross Mountains (Central Poland). Acta Geologica Polonica 54, 401-406.

SzReK, P. 2006a. Zróżnicowanie facjalne a skamieniałości późnodewońskich plakodermów w Górach Świętokrzyskich. Przegląd Geologiczny 54, 521-524.

Szrek, P. 2006b. Skamieniałości Antiarcha (Vertebrata, Placodermi) w dewonie Gór Świętokrzyskich. Przegląd Geologiczny 54, 610-614.

SzReK, P. 2007a. The facies-related distribution of placoderms in the Late Devonian of the Holy Cross Mountains. Ichthyolith Issues 10, 85-86.

SzREK, P. 2007b. Ryby pancerne a zapis górnego zdarzenia Kellwasser w Płuckach koło Łagowa, 133-134. In ŻYLIŃSKA, A. (ed.) Granice Paleontologii, XX Konferencja Paleobiologów i Biostratygrafów PTG, Św. Katarzyna pod Łysica, 10-13 września 2007. Warszawa.

Szrek, P. 2007c. Coelacanths (Actinistia, Sarcopterygii) from the Famennian (Upper Devonian) of Kadzielnia Chain, Holy Cross Mountains, Poland. Acta Geologica Polonica 57, 403-413.

SzReK, P. 2008. Vertebrates from the upper Kellwasser limestone, Frasnian-Famennian boundary beds (Upper Devonian) of the Holy Cross Mountains (Poland). Journal of Vertebrate Paleontology 28, p. 150.

SzreK, P. 2009. Devonian placoderms from the Holy Cross Mountains, Poland. 144 pp. Ph.D. thesis. Faculty of Geology, University of Warsaw, Warsaw, Poland.

Szrek, P. \& Dupret, V. 2017. Placoderms from the Early Devonian "placoderm sandstone" of the Holy Cross Mountains, Poland with biostratigraphical and palaeobiogeographical implications. Acta Palaeontologica Polonica 62, 789-800. DOI 10.4202/app.00395.2017

Szrek, P. \& Ginter, M. 2007. Poziomy wapieni typu Kellwasserkalk w Płuckach koło Łagowa, 157-161. In ŻylińsKa, A. (ed.) Granice Paleontologii, XX Konferencja Paleobiologów i Biostratygrafów PTG, Św. Katarzyna pod Eysica, 10-13 września 2007. Warszawa.

Szrek, P. \& Niedźwiedzki, G. 2015. Placoderm faunas from the Lower to Upper Devonian of the Holy Cross Mountains. In Trinajstic, K., Johanson, Z., Richter, M. \& Boisvert, C. (eds) $13^{\text {th }}$ International Symposium on Early and Lower Vertebrates, Royal Society of Victoria, Melbourne, Australia, August $3^{\text {rd }}-7^{\text {th }} 2015$.

Szrek, P. \& WiLK, O. 2018. A large Late Devonian arthrodire (Vertebrata, Placodermi) from Poland. Estonian Journal of Earth Sciences 67, 33-42. DOI 10.3176/earth.2018.02 
Szrek, P., Dec, M. \& Niedźwiedzki, G. 2015. The first placoderm fish from the Lower Devonian of Poland. Journal of Vertebrate Paleontology 35, e930471. DOI 10.1080/02724634.2014.930471

Szrek, P., Niedźwiedzki, G. \& Dec, M. 2014. Storm origin of bone-bearing beds in the Lower Devonian placoderm sandstone from Podłazie Hill (Holy Cross Mountains, central Poland). Geological Quarterly 58, 795-806. DOI 10.7306/gq.1191

Szrek, P., Salwa, S., Niedźwiedzki, G., Dec, M., Ahlberg, P.E. \& UCHMAN, A. 2016. A glimpse of a fish face - an exceptional fish feeding trace fossil from the Lower Devonian of the Holy Cross Mountains, Poland. Palaeogeography, Palaeoclimatology, Palaeoecology 454, 113-124. DOI 10.1016/j.palaeo.2016.04.019

Szulczewski, M. 1968. Slump structures and turbidites in Upper Devonian limestones of the Holy Cross Mountains. Acta Geologica Polonica 17, 303-324.

Szulczewski, M. 1971. Upper Devonian conodonts, stratigraphy and facies development in the Holy Cross Mountains. Acta Geologica Polonica 21, 1-129.

SzULCZEWSKI, M. 1973. Famennian-Tournaisian neptunian dykes and their conodont fauna from Dalnia in the Holy Cross Mountains. Acta Geologica Polonica 23, 15-59.

Szulczewski, M. 1989. Światowe i regionalne zdarzenia w zapisie stratygraficznym pogranicza franu i famenu Gór Świętokrzyskich. Przegląd Geologiczny 37, 551-557.

Szulczewski, M. 1995. Depositional evolution of the Holy Cross Mountains in the Devonian and Carboniferous - a review. Geological Quarterly 39, 471-488.

Szulczewski, M. 2006. Ewolucja środowisk depozycyjnych w dewonie świętokrzyskim i jej uwarunkowania, 56-62. In SKOMPSKI, S. \& ŻYLIŃSKA, A. (eds) Procesy i zdarzenia $w$ historii geologicznej Gór Świętokrzyskich, 77 Zjazd Naukowy PTG, Ameliówka k. Kielc, 28-30 czerwca 2006 r.

Szulczewski, M. \& PoręBski, S. 2008. Stop 1 - Bukowa Góra, Lower Devonian, 18-37. In Pieńkowski, G. \& Uchman, A. (eds) Ichnological Sites of Poland. The Holy Cross Mountains and the Carpathian Flysch. The Second International Congress on Ichnology. Cracow, Poland, August 29 September 8, 2008. The Pre-Congress and Post-Congress Field Trip Guidebook, Polish Geological Institute.

Szulczewski, M., BeŁka, Z. \& Skompski, S. 1996. The drowning of a carbonate platform: an example from the DevonianCarboniferous of the Holy Cross Mountains, Poland. Sedimentary Geology 106, 21-49.

DOI 10.1016/0037-0738(95)00145-X

TARLO, L.B. 1957. A preliminary note on new ostracoderms from the Lower Devonian (Emsian) of central Poland. Acta Palaeontologica Polonica 2, 225-233.

TARLO, L.B. 1961a. Rhinopteraspis cornubica (McCoy), with notes on the clssification and evolution of the pteraspids. Acta Palaeontologica Polonica 6, 367-402.

TARLO, L.B. 1961b. Psammosteids from the Middle and Upper Devonian of Scotland. Quarterly Journal of the Geological Society of London 117, 367-402.

DOI 10.1144/gsjgs.117.1.0193

TARlo, L.B. 1962. The classification and evolution of the Heterostraci. Acta Palaeontologica Polonica 7, 249-286.

TARLo, L.B. 1964. Psammosteiformes (Agnatha) - a review with descriptions of new material from the Lower Devonian of Poland. I - general part. Palaeontologia Polonica 13, 1-135.

TARLO, L.B. 1965. Psammosteiformes (Agnatha) - a review with descriptions of new material from the Lower Devonian of Poland. II - systematic part. Palaeontologia Polonica 15, $1-168$.

TARNOWSKA, M. 1976. Lithological correlation of the Lower Devonian in the eastern part of the Holy Cross Mountains. Biuletyn Instytutu Geologicznego 296, 75-115.

VašKaninová, V. \& Kraft, P. 2014. Dynamics of placoderm distribution in the Prague Basin (Czech Republic). GFF 136, 281-285. DOI 10.1080/11035897.2014.880510

White, E.I. 1978. The larger arthrodiran fishes from the area of the Burrinjuck Dam, NSW. Transactions of the Zoological Society of London 34, 149-262. DOI 10.1111/j.1096-3642.1978.tb00374.x

Woroncowa-Marcinowska, T. \& Szrek, P. 2004. Zbiory Jana Czarnockiego w Muzeum Geologicznym PIG - nieustające źródło badań. Przegląd Geologiczny 52, 638-639.

Woodward, A.S. 1885. Guide to the collection of fossil fishes in the Department of Geology and Paleontology, British Museum (Natural History). 47 pp. Trustees British Museum (Natural History), London.

Woodward, A.S. 1891. Catalogue of the fossil fishes in the British Museum (Natural History). Part II. 567 pp. London. DOI 10.5962/bhl.title.162355 